\title{
Alterations in novel candidate tumor suppressor genes, ING1 and ING2 in human lung cancer
}

\author{
TETSUYA OKANO $^{1}$, AKIHIKO GEMMA ${ }^{1}$, YOKO HOSOYA ${ }^{1}$, YUKIO HOSOMI ${ }^{1}$, MICHIYA NARA $^{1}$, \\ YUTAKA KOKUBO $^{1}$, AKINOBU YOSHIMURA ${ }^{1}$, MASAHIKO SHIBUYA ${ }^{1}$, \\ MAKOTO NAGASHIMA ${ }^{2}$, CURTIS C. HARRIS ${ }^{2}$ and SHOJI KUDOH ${ }^{1}$ \\ ${ }^{1}$ Fourth Department of Internal Medicine, Nippon Medical School, Tokyo, Japan; ${ }^{2}$ Laboratory of Human Carcinogenesis, \\ National Cancer Institute, National Institutes of Health, Bethesda, MD, USA
}

Received September 28, 2005; Accepted November 21, 2005

\begin{abstract}
The INGI gene is involved in the regulation of the cell cycle, senescence, and apoptosis and is a novel candidate tumor suppressor gene. ING2, another gene in the $I N G$ family, was identified and cloned. The functions of INGI and $I N G 2$ largely depend on the activity of p53. To determine whether an alteration in these genes plays a role in carcinogenesis and tumor progression in lung cancer, we screened 30 human lung cancer cell lines and 31 primary lung cancer tumors for mutations in these genes using polymerase chain reaction-single strand conformation polymorphism (PCR$\mathrm{SSCP}$ ) and direct sequencing. Our findings failed to uncover any mutations in these genes. We also examined the expression of ING1 and ING2 in lung cancer cell lines that either had or lacked a $p 53$ mutation, and in a control bronchial epithelium cell line, using quantitative real-time reverse transcriptionpolymerase chain reaction (RT-PCR). ING1 expression was up-regulated in all 7 lung cancer cell lines that had a $p 53$ mutation, while the expression of $I N G 2$ was down-regulated in 6 of 7 lung cancer cell lines that had a p53 mutation. These results suggest that the ING1 and ING2 genes have different roles in lung carcinogenesis and progression, and the ING2 gene may be an independent tumor suppressor candidate on p53.
\end{abstract}

\section{Introduction}

Human cancers develop as a result of the stepwise accumulation of multiple acquired genetic defects that include

Correspondence to: Dr Akihiko Gemma, Fourth Department of Internal Medicine, Nippon Medical School, 1-1-5, Sendagi, Bunkyo-ku, Tokyo, 113-8602, Japan

E-mail: agemma@nms.ac.jp

Key words: ING1, ING2, lung cancer, polymorphism, mRNA expression mutations in tumor suppressor genes. A mutation in the p53 tumor suppressor gene is the most frequently identifiable defect in human cancers (1). Other candidate tumor suppressor genes have been cloned and are referred to as ING (2). ING1, which is located on chromosome 13q 33 34 (3) and was found to encode a nuclear protein, consists of exons $1 \mathrm{a}, 1 \mathrm{~b}$, and 2 (4). Four alternatively spliced transcripts of INGI encode INGIa, ING1b, INGIc and ING1d (4-6). ING2 was cloned and mapped to human chromosome $4 \mathrm{q} 35$ by fluorescence in situ hybridization and radiation-hybrid analyses (GenBank accession no. AF053537) $(7,8)$. Overexpression of ING1 and ING2 led to growth arrest in the G1 phase of the cell cycle and induced apoptosis in several cell types $(2,8,9)$ that largely depend on the activation of p53 $(8,10)$. ING family proteins contain a region that is homologous to plant homeodomain (PHD) finger domains and have been implicated in chromatin-mediated transcriptional regulation $(2,11)$.

ING1 gene mutations are rare in many human cancers, and no report exists on $I N G 2$ gene mutation analysis in human cancers. Reduced expression of the INGI gene has been reported in breast (12) and gastric cancers (13), and in lymphoid malignancies (14).

To determine whether alterations in the $I N G I b$ and/or $I N G 2$ genes are involved in lung carcinogenesis, lung cancer cell lines and primary tumors were examined for such mutations using polymerase chain reaction-single strand conformation polymorphism (PCR-SSCP) and DNA sequence analysis. In addition, the expression of $I N G I b$ and $I N G 2$ was analyzed in lung cancer cell lines using real-time quantitative reverse transcription (RT)-PCR.

\section{Materials and methods}

Tissue samples. Primary lung cancers $(\mathrm{n}=31)$ and matched control samples were obtained during autopsy of patients previously been admitted to the Fourth Department of Internal Medicine at the Nippon Medical School Main Hospital in Tokyo, Japan, and immediately frozen at $-80^{\circ} \mathrm{C}$. The samples included 14 adenocarcinomas, 8 squamous cell carcinomas (SCCs), 6 small cell lung cancers (SCLCs), 2 large cell carcinomas, and 1 adenosquamous cell carcinoma. 
Table I. Sequence of the polymerase chain reaction (PCR) primer used for amplification of the indicated exons in $I N G 1 b$ and ING2.

\begin{tabular}{|c|c|c|c|}
\hline Exon & & Sense primer sequence & Antisense primer sequence \\
\hline \multicolumn{4}{|l|}{$I N G 1 b$} \\
\hline Exon 1 & & TGCAGTGCTATTTTTTGAGGGG & CGCCCCCGCCCATCCATCA \\
\hline \multirow[t]{4}{*}{ Exon 2} & a & ACGCCTGTCCTTCTTGCCCC & CTTGCCGCTGTTGCCCGCTG \\
\hline & $\mathrm{b}$ & TTCGAGGCGCAGCAGGAGCT & СTTGGCCTTCTTCTCCTTGGG \\
\hline & $\mathrm{c}$ & CAGCAACCACGACCACGACG & TGAGCCCCACGCACGAGAAG \\
\hline & d & CCTCCCCATCGACCCCAACG & ACATTTTACACTCCTTGCACCTCA \\
\hline \multicolumn{4}{|l|}{ ING2 } \\
\hline Exon 1 & & TGCATGTGCGGCTGCTGGATG & TGTCACGGGAGAAAGGGAAG \\
\hline \multirow[t]{3}{*}{ Exon 2} & a & CCTTGGAAATGTTGTGTCTGC & TTCTGGTTGGCTGGAATCC \\
\hline & $\mathrm{b}$ & TGCTGAAAGTGAACGAGCCTC & TCСТАТСАТСТССССАTAAGACAC \\
\hline & $\mathrm{c}$ & AAAGAAACGCTCCAAGGC & СССТTTAAAATGTGGATGGCC \\
\hline
\end{tabular}

Table II. Sequence of primer and probe used in the real-time reverse transcription-polymerase chain reaction (RT-PCR) indicated gene.

\begin{tabular}{llll}
\hline Gene & Sense primer sequence & Antisense primer sequence & Probe sequence \\
\hline ING1b & CGAAATACCAAGAGATCCTGAAGG & TGCGCCCCGTCTGTCT & ACGAGTGCTACGAGCGCTTCAGTCG \\
$I N G 2$ & GGACTACCTTGAGTGCGTGGA & TCGCAGCACAGACACGTTC & TCGCTGCCCCACGACATGCA \\
GAPDH & GAAGGTGAAGGTCGGAGTC & GAAGATGGTGATGGGATTC & CAAGCTTCCCGTTCTCAGCC \\
\hline
\end{tabular}

GAPDH, glyceraldehyde-3-phosphate dehydrogenase.

Lung cancer cell lines. A total of 15 human non-small cell lung cancers (PC1, PC3, PC7, PC9, PC10, PC13, PC14, Lu65, A427, A549, NCI-H23, NCI-H157, NCI-H358, NCIH441, and NCI-H520) and 15 human small cell lung cancers (Lu24, Lu130, Lu134, Lu135, Lu138, Lu139, Lu140, Lu141, NCI-H69, NCI-H82, NCI-H526, NCI-N230, NCI-N231, NCI-N417, and SBC5) were used for DNA analysis (15). The Lu24, Lu65, and Lu135 cell lines were provided by Dr Y. Shimosato and Dr T. Terasaki (National Cancer Center Research Institute, Tokyo, Japan). The NCI-N231, A549, A427, NCI-H358, NCI-H157, NCI-H23, NCI-H441, NCIH520, NCI-H82, NCI-N417, NCI-H526, and NCI-H69 cell lines were obtained from the American Type Culture Collection (Rockville, MD) (16), while the PC1, PC3, PC7, PC9, PC10, and PC14 cell lines were obtained from Immuno-Biological Laboratories (Gunma, Japan). The Lu24, Lu130, Lu134, Lu138, Lu139, Lu140, Lu141, and SBC-5 cell lines were provided by Dr J. Yokota (National Cancer Center Research Institute). We also performed transcriptional studies on 8 lung cancer cell lines (NCI-N231, Lu65, A549, NCI-H69, Lu135, PC7, PC9, and PC14) and on a normal human bronchial epithelial cell line (BET2A; American Type Culture Collection, no. ATCC CRL-9443).

DNA and RNA isolation. Genomic DNA was extracted from tumor and normal cells by proteinase $\mathrm{K}$ treatment and phenol chloroform extraction using standard protocols. RNAs were prepared using standard protocols described previously (17).
Polymerase chain reaction-single strand conformation polymorphism (PCR-SSCP) analysis. PCR-SSCP analysis was performed as previously described $(16,18)$. Each of the two exons of the INGIb and ING2 genes was amplified separately using the PCR primers shown in Table I. PCR was performed using the Gene AMP XL PCR kit (Perkin-Elmer Corp./Roche, Branchburg, NJ), which was followed by 40 cycles of denaturation at $94^{\circ} \mathrm{C}$ for $40 \mathrm{sec}$, annealing at $55^{\circ} \mathrm{C}$ for $30 \mathrm{sec}$, and extension at $68^{\circ} \mathrm{C}$ for $90 \mathrm{sec}$, with a final extension at $68^{\circ} \mathrm{C}$ for $8 \mathrm{~min}$. The PCR reaction mixture contained XL buffer with $110 \mu \mathrm{M} \mathrm{Mg}(\mathrm{OAc})_{2}, 200 \mu \mathrm{M}$ deoxynucleotide triphosphate, $0.1 \mathrm{mM}$ of each primer labeled with 5-IAF (Amersham Pharmacia Biotech, Uppsala, Sweden), 0.5 units of rTth DNA polymerase, and $25 \mathrm{ng}$ of genomic DNA. The 5-IAF-labeled PCR products were denatured, cooled on ice, and loaded on neutral $6 \%$ polyacrylamide gels with or without $5 \%(\mathrm{vol} / \mathrm{vol})$ glycerol. Following electrophoresis, the gels were analyzed using the FluorImager 595 (Amersham Pharmacia Biotech).

DNA sequence analysis. DNA sequence analysis was performed as previously described $(16,18)$. Aberrant bands were cut from the gel and further amplified by PCR using sequencing primers with the M13 sequence (TGTAAAACG ACGGCCAGT) added to the appropriate PCR primers. PCR was performed as described above, and the products were purified and sequenced using a fluorescent automated sequencer (Perking-Elmer Corp./Applied Biosystem, Inc., Foster City, CA, USA). 
A

I
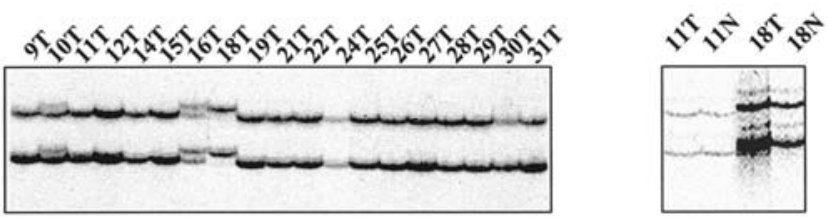

B

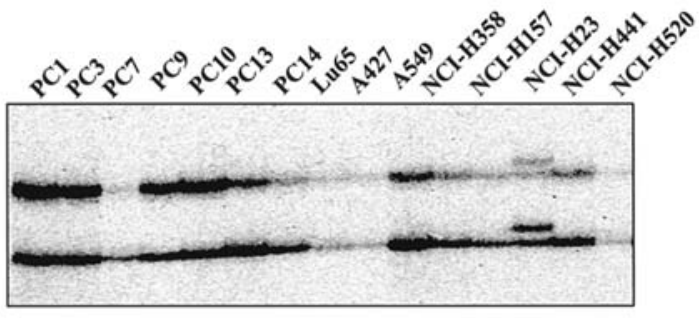

$\mathrm{C}$

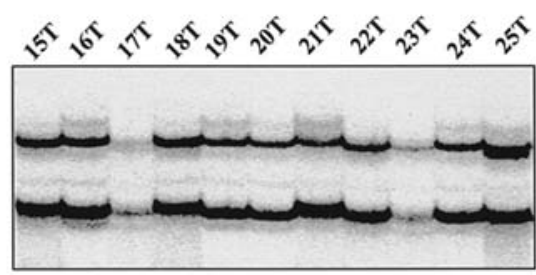

Figure 1. (A) PCR-SSCP analysis of exon 2 of the $I N G 1 b$ gene showed mobility shifts in lung cancer tissues [tumors (T) 10, 12, 16, and 18]. Tumor (T) and normal tissue $(\mathrm{N})$ from case 18 showed similar patterns on PCRSSCP. (B) PCR-SSCP analysis of exon 2 of the $I N G 1 b$ gene showed an aberrant band in lung cancer cell line NCI-H23. (C) PCR-SSCP analysis of exon 1 of the ING2 gene showed mobility shifts in the lung cancer tissues of cases 15,18 , and 21 .

Real-time quantitative reverse transcription-polymerase chain reaction ( $R T-P C R)$. RT quantitative-PCR was performed using the ABI Prism 7700 sequence detector (Perkin-Elmer Corp./ Applied Biosystem, Inc.). The PCR primers and the Taq Man fluorescence probes (Table II) were designed using the Primer Express software program (Perkin-Elmer Corp./Applied Biosystem, Inc.). The total RNA sample $(1 \mu \mathrm{g})$ was reverse transcribed using a random hexamer and a pre-amplification system (Life Technologies). A portion of each cDNA was used for quantitative PCR in a volume of $50 \mu 1$, and the reaction mixture contained the designed primers, Taqman probes, and Master Mix that included the PCR buffer, $\mathrm{MgCl}_{2}$, dATP, dCTP, dGTP, dUTP, AmpErase UNG, and AmpliTaq Gold DNA polymerase (Perkin-Elmer Corp./Applied Biosystem, Inc.). PCR was carried out at $50^{\circ} \mathrm{C}$ for $2 \mathrm{~min}$, then $95^{\circ} \mathrm{C}$ for $10 \mathrm{~min}$, followed by 40 cycles at $95^{\circ} \mathrm{C}$ for $15 \mathrm{sec}$ and $60^{\circ} \mathrm{C}$ for $1 \mathrm{~min}$. The degree of gene expression was reported as the ratio of a given gene's mRNA in a particular sample to the level of GAPDH mRNA in that sample.

\section{Results}

Mutation analysis of the ING1b and ING2 genes in human lung cancers and lung cancer cell lines. PCR-SSCP analysis
A
I

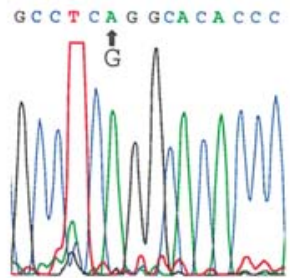

B

I $\underset{T}{\operatorname{TsGCGCTCTGA}}$

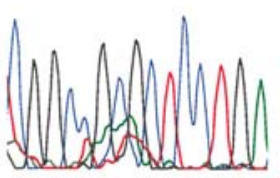

$\mathrm{C}$

I

TAG G A A $\underset{\mathbf{t}}{\mathbf{t}}$

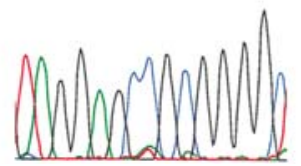

II

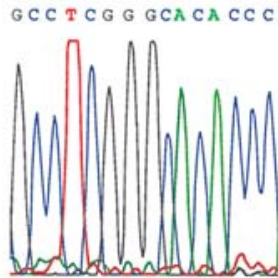

II

CGGCT GCGCTCCTG A

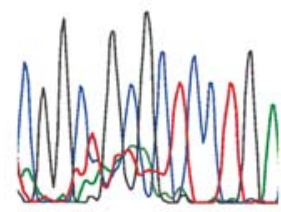

II

TA G G G GC CGCG G G GC

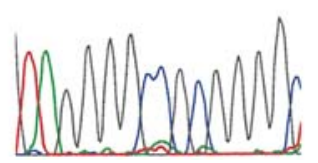

Figure 2. (A), Sequence analysis revealed a nucleotide substitution $(\mathrm{G} \rightarrow \mathrm{A}$, serine to serine) at codon 173 of exon 2 of the $I N G 1 b$ gene in case 16 . I, DNA sequence of case 16; II, control. (B) DNA sequence of exon 1 of the $I N G 2$ gene revealed a nucleotide substitution $(\mathrm{T} \rightarrow \mathrm{C}$, alanine to alanine) at codon 13. I, case 15; II, control. (C) DNA sequence of exon 1 of the ING2 gene revealed a nucleotide substitution $(\mathrm{G} \rightarrow \mathrm{A}) 6$ bp downstream of exon 1 . I, case 15 ; II, control.

of exon 2 of the INGIb gene revealed aberrant bands in 6 of 31 lung cancer tissues (cases 5, 6, 10, 12, 16 and 18) with or without normal bands (Fig. 1A), and 1 of the 30 lung cancer cell lines i.e. NCI-H23, which is a non-small cell lung cancer (Fig. 1B). DNA sequence analysis of these bands revealed a $\mathrm{G}$ to $\mathrm{A}$ substitution at codon 173 (Fig. 2A), which does not result in an amino acid substitution. Matched normal tissues had these same aberrant bands, which suggested that they were due to polymorphisms. In exon 1 of the ING2 gene, we detected aberrant bands in 6 of 31 lung cancer tissues (cases 5, 8, 12, 15, 18 and 21) with or without normal bands (Fig. 1C). Sequencing of these bands showed a $\mathrm{T}$ to $\mathrm{C}$ substitution at codon 13 (Fig. 2B) that did not alter the encoded amino acid, and a $\mathrm{G}$ to A substitution in the noncoding region of intron 1 of the ING2 gene 6 bp downstream of exon 1 (Fig. 2C), which also appeared to be due to polymorphisms.

Expression of mRNA for INGIb and ING2 in human lung cancers and lung cancer cell lines. The expression of INGIb mRNA was up-regulated in 7 of 8 lung cancer cell lines compared to the human bronchial epithelium cell line, 
Table III. INGIb mRNA levels in lung cancer cell lines.

\begin{tabular}{lcc}
\hline cDNA & $I N G 1 b / G A P D H$ & Fold difference $^{\mathrm{a}}$ \\
\hline NCI-N231 & 6.743 & 6.643 \\
Lu65 & 5.298 & 5.220 \\
A549 & 1.490 & 1.468 \\
NCI-H69 & 10.952 & 10.790 \\
Lu135 & 5.710 & 5.626 \\
PC7 & 14.297 & 14.086 \\
PC9 & 2.241 & 2.208 \\
PC14 & 2.281 & 2.247
\end{tabular}

${ }^{\mathrm{a}}$ Fold difference, intensity of INGIb expression of sample/intensity of its expression in BET2A.

Table IV. ING2 mRNA levels in lung cancer cell lines.

\begin{tabular}{lcc}
\hline cDNA & $I N G 2 / G A P D H$ & Fold difference $^{\mathrm{a}}$ \\
\hline NCI-N231 & 0.382 & 0.288 \\
Lu65 & 0.737 & 0.555 \\
A549 & 0.340 & 0.256 \\
NCI-H69 & 0.375 & 0.282 \\
Lu135 & 0.381 & 0.287 \\
PC7 & 0.280 & 0.211 \\
PC9 & 0.086 & 0.065 \\
PC14 & 0.491 & 0.370 \\
\hline
\end{tabular}

${ }^{a}$ Fold difference, intensity of $I N G 2$ expression of sample/intensity of its expression in BET2A.

Table V.p53 status in lung cancer cell line.

\begin{tabular}{lcrcc}
\hline Cell line & Type of mutation & Codon & Exon & Change \\
\hline NCI-N231 & Missense & 298 & 8 & GAG $\rightarrow$ TAG \\
Lu65 & Missense & 11 & 2 & GAG $\rightarrow$ CAG \\
A549 & Wild-type & & & \\
NCI-H69 & Missense & 171 & 5 & GAG $\rightarrow$ TAG \\
Lu135 & Missense & 244 & 7 & GGC $\rightarrow$ TGC \\
PC7 & Missense & 214 & 6 & CAT $\rightarrow$ CGT \\
PC9 & Missense & 248 & 7 & CGG $\rightarrow$ CAG \\
PC14 & Missense & 248 & 7 & CGG $\rightarrow$ TGG \\
\hline
\end{tabular}

BET2A (Table III). All 7 cell lines with up-regulated ING1b mRNA had a $p 53$ mutation, and the remaining cell line expressed wild-type $p 53$. The expression of ING2 mRNA was down-regulated in 7 of 8 lung cancer cells (Table IV). Six of the 7 cell lines that had a $p 53$ mutation also showed reduced $I N G 2$ mRNA expression. The mean relative intensity of $I N G 1 b$ and $I N G 2$ expression (intensity of $I N G$ expression of sample/intensity of its expression in BET2A) was $6.036(1.468-14.086)$ and 0.289 (0.065-0.555), respectively $(\mathrm{p}<0.01$ using a paired $\mathrm{t}$-test).

\section{Discussion}

Mutation of the ING1 gene has previously been reported in neuroblastoma (2) and gastrointestinal cancer cell lines (13), breast tumors (12), esophageal squamous cell tumors (19), and head and neck squamous cell carcinomas (4). Although ING1 gene mutations are rare in many human cancers, INGI expression is down-regulated in several types of human cancers including breast (12), gastric (13), esophageal (19), and lymphoid cancers (14). The INGl gene may serve as a type II tumor suppressor since it inactivates cellular function at transcriptional and post-transcriptional levels (20).

We studied the degree of mutation and expression of the $I N G 1 b$ and ING2 genes in human lung cancer cell lines and tumors. No point mutations in the INGIb and $I N G 2$ genes were found in human lung cancers. However, we did observe a single polymorphism at codon 173 (G-to-A) in exon 2 of the INGIb gene. This polymorphism has previously been reported in Indian patients with oral squamous cell carcinoma (21) and Japanese breast cancer patients, but not in Canadian cancer patients (12). We also detected a single polymorphism in exon 1 and intron 1 of the ING2 gene. There were differences in the frequency of polymorphisms between cancer tissues and cell lines in this study. The cancerous tissues were obtained from Japanese patients, while the cell lines were nearly all established in the U.S. Thus, this polymorphism may be more frequent in Japanese patients.

ING proteins have a PHD finger motif that plays a role in chromatin remodeling $(11,22)$, and nuclear localization sequences (NLS) and nucleolar targeting sequences (NTS) (23) that can target ING proteins to nucleoli when ING proteins are overexpressed. One such protein, $I N G l b$, has been shown to bind to proliferating cell nuclear antigen (PCNA) through the PCNA-interacting protein (PIP) domain after DNA damage, and to regulate the induction of apoptosis (24) and enhance the repair of UV-damaged DNA (25). This protein contains histone acetyltransferase (HAT) (26-29) and histone deacetyltransferase (HDAC) $(30,31)$. On the other hand, INGIa was shown to inhibit histone acetylation by binding to HDAC1 complexes (29). These findings suggest that $I N G I b$ may regulate the switch from DNA replication to DNA repair.

Previous studies reported that ING2 mRNA expression was up-regulated in human colon cancers (7). By Western blot analysis, the expression of ING2 protein was found to be diminished in colorectal and hepatocellular carcinomas, and prostate and pancreatic cancers (8). ING2 was shown to negatively regulate cell proliferation through the induction of p53 acetylation at lysine 382 (8), and activation of p53 by acetylation reportedly resulted in the induction of growth inhibitor genes and proteins that activated the mitochondrial apoptotic pathway through the release of cytochrome C (32). In this study, ING2 mRNA expression was found to be primarily down-regulated in lung cancer cell lines. Previous studies have reported that the overexpression of $I N G I b$ and $I N G 2$ negatively regulated cell growth through the induction of apoptosis and G1-phase cell cycle arrest in a p53dependent manner $(2,8,9)$. It is interesting that lung cancer cells with inactivated $\mathrm{p} 53$ had reduced expression of the ING2 gene in our study (Table V). It has been reported that 
the expression of ING1 and ING2 was independent of $p 53$ status $(8,33)$.

Our results suggest that mutations in the $I N G I b$ gene are rare, and its mRNA expression is primarily up-regulated in lung cancers. Inactivation of the p53 gene in lung cancers may play a role in the overexpression of the $I N G 1 b$ gene. Our results suggest that the inactivation of ING2 may play an important role in the development and/or progression of lung cancer, even in cancers that exhibit a $p 53$ mutation. Since the $I N G 2$ gene was not mutated in these cancer cells, the ING2 gene may have been negatively transcriptionally regulated, possibly as a result of hypermethylation of the gene promoter or transcriptional factor.

\section{Acknowledgements}

This work was supported by a Grant-in-Aid for Scientific Research from the Japan Society for the Promotion of Science and the Ministry of Education, Culture, Sports, Science and Technology of Japan (to A.G. and S.K.).

\section{References}

1. Hollstein M, Sidransky D, Vogelstein B and Harris CC: p53 mutations in human cancers. Science 253: 49-53, 1991.

2. Garkavtsev I, Kazarov A, Gudkov A and Riabowol K: Suppression of the novel growth inhibitor $\mathrm{p} 33^{\mathrm{ING} 1}$ promotes neoplastic transformation. Nat Genet 14: 415-420, 1996.

3. Garkavtsev I, Demetrick D and Riabowol K: Cellular localization and chromosome mapping of a novel candidate tumor suppressor gene (ING1). Cytogenet Cell Genet 76: 176-178, 1997.

4. Gunduz M, Ouchida M, Fukushima K, Hanafusa H, Etani T, Nishioka S, Nishizaki K and Shimizu K: Genomic structure of the human ING1 gene and tumor-specific mutations detected in head and neck squamous cell carcinomas. Cancer Res 60: 3143-3146, 2000.

5. Garkavtsev I: Correction and addition to ING1 sequences. Nat Genet 23: 373, 1999.

6. Saito A, Furukawa T, Fukushige S, Koyama S, Hoshi M, Hayashi Y and Horii A: p24/ING1-ALT1 and p47/ING1-ALT2, distinct alternative transcripts of p33/ING1. J Hum Genet 45: $177-181,2000$

7. Shimada Y, Saito A, Suzuki M, Takahashi E and Horie M: Cloning of a novel gene (ING1L) homologous to ING1, a candidate tumor suppressor. Cytogenet Cell Genet 83: 232-235, 1998.

8. Nagashima M, Shiseki M, Miura K, Hagiwara K, Linke SP, Pedeux R, Wang XW, Yokota J, Riabowol K and Harris CC: DNA damage-inducible gene p33ING2 negatively regulates cell proliferation through acetylation of p53. Proc Natl Acad Sci USA 98: 9671-9676, 2001.

9. Helbing CC, Veillette C, Riabowol K, Johnston RN and Garkavtsev I: A novel candidate tumor suppressor, ING1, is involved in the regulation of apoptosis. Cancer Res 57: 1255-1258, 1997.

10. Garkavtsev I, Grigorian IA, Ossovskaya VS, Chernov MV, Chumakov PM and Gudkov AV: The candidate tumour suppressor $\mathrm{p} 33^{I N G 1}$ cooperates with $\mathrm{p} 53$ in cell growth control. Nature 391: 295-298, 1998.

11. Aasland R, Gibson TJ and Stewart AF: The PHD finger: implications for chromatin mediated transcriptional regulation. Trends Biochem Sci 20: 56-59, 1995.

12. Toyama T, Iwase H, Watson P, Muzik H, Saettler E, Magliocco A, DiFrancesco L, Forsyth P, Garkavtsev I, Kobayashi S and Riabowol K: Suppression of ING1 expression in sporadic breast cancer. Oncogene 18: 5187-5293, 1999.

13. Oki E, Maehara Y, Tokunaga E, Kakeji Y and Sugimachi K: Reduced expression of $\mathrm{p} 33^{\mathrm{ING} 1}$ and the relationship with $\mathrm{p} 53$ expression in human gastric cancer. Cancer Lett 147: 157-162, 1999.

14. Ohmori M, Nagai M, Tasaka T, Koeffler HP, Toyama T, Riabowol K and Takahara J: Decreased expression of $\mathrm{p} 33^{I N G 1}$ mRNA in lymphoid malignancies. Am J Hematol 62: 118-119, 1999.
15. Gemma A, Takenoshita S, Hagiwara K, Okamoto A, Spillare EA, McMemamin MG, Hussain SP, Forrester K, Zariwala M, Xiong Y and Harris CC: Molecular analysis of the cyclin-dependent kinase inhibitor genes p15INK4b/MTS2, p16INK4/MTS1, p18 and p19 in human cancer cell lines. Int J Cancer 68: 605-611, 1996.

16. Gemma A, Hagiwara K, Ke Y, Burke LM, Khan MA, Nagashima M, Bennett WP and Harris CC: FHIT mutations in human primary gastric cancer. Cancer Res 57: 1435-1437, 1997.

17. Gemma A, Takenaka K, Hosoya Y, Matuda K, Seike M, Kurimoto F, Ono Y, Uematsu K, Takeda Y, Hibino S, Yoshimura A, Shibuya M and Kudoh S: Altered expression of several genes in highly metastatic subpopulations of a human pulmonary adenocarcinoma cell line. Eur J Cancer 37: 1554-1561, 2001.

18. Gemma A, Hagiwara K, Vincent F, Ke Y, Hancock AR, Nagashima M, Bennett WP and Harris CC: hSmad5 gene, a human hSmad family member: its full length cDNA, genomic structure, promoter region and mutation analysis in human tumors. Oncogene 16: 951-960, 1998.

19. Chen L, Matsubara N, Yoshino T, Nagasaka T, Hoshizima N, Shirakawa Y, Naomoto Y, Isozaki H, Riabowol K and Tanaka N: Genetic alterations of candidate tumor suppressor ING1 in human esophageal squamous cell cancer. Cancer Res 61: 4345-4349, 2001.

20. Sager R: Expression genetics in cancer: shifting the focus from DNA to RNA. Proc Natl Acad Sci USA 94: 952-955, 1997.

21. Krishnamurthy J, Kannan K, Feng J, Mohanprasad BK, Tsuchida $N$ and Shanmugam G: Mutational analysis of the candidate tumor suppressor gene ING1 in Indian oral squamous cell carcinoma. Oral Oncol 37: 222-224, 2001.

22. Vieyra D, Toyama T, Hara Y, Boland D, Johnston R and Riabowol K: ING1 isoforms differentially affect apoptosis in a cell age-dependent manner. Cancer Res 62: 4445-4452, 2002.

23. Scott M, Boisvert FM, Vieyra D, Johnston RN, Bazett-Jones DP and Riabowol K: UV induces nucleolar translocation of ING1 through two distinct nucleolar targeting sequences. Nucleic Acids Res 29: 2052-2058, 2001.

24. Scott M, Bonnefin P, Vieyra D, Boisvert FM, Young D, Bazett-Jones DP and Riabowol K: UV-induced binding of ING1 to PCNA regulates the induction of apoptosis. J Cell Sci 114: 3455-3462, 2001.

25. Cheung KJ Jr, Mitchell D, Lin P and Li G: The tumor suppressor candidate $\mathrm{p} 33^{\mathrm{ING} 1}$ mediates repair of UV-damaged DNA. Cancer Res 61: 4974-4977, 2001.

26. Loewith R, Meijer M, Lees-Miller SP, Riabowol K and Young D: Three yeast proteins related to the human candidate tumor suppressor $\mathrm{p} 33^{\text {ING1 }}$ are associated with histone acetyltransferase activities. Mol Cell Biol 20: 3807-3816, 2000.

27. Nourani A, Doyon Y, Utley RT, Allard S, Lane WS and Cote J: Role of an ING1 growth regulator in transcriptional activation and targeted histone acetylation by the NuA4 complex. Mol Cell Biol 21: 7629-7640, 2001.

28. Howe L, Kusch T, Muster N, Chaterji R, Yates JR 3rd and Workman JL: Yng1p modulates the activity of Sas $3 p$ as a component of the yeast $\mathrm{NuA} 3$ histone acetyltransferase complex. Mol Cell Biol 22: 5047-5053, 2002.

29. Vieyra D, Loewith R, Scott M, Bonnefin P, Boisvert FM, Cheema P, Pastyryeva S, Meijer M, Johnston RN, McMahon S, Bazett-Jones DP, Cole MD, Young D and Riabowol K: Human ING1 proteins differentially regulate histone Acetylation. J Biol Chem 277: 29832-29839, 2002.

30. Skowyra D, Zeremski M, Neznanov N, Li M, Choi Y, Uesugi M, Hauser CA, Gu W, Gudkov AV and Qin J: Differential association of products of alternative transcripts of the candidate tumor suppressor ING1 with the mSin3/HDAC1 transcriptional corepressor complex. J Biol Chem 276: 8734-8739, 2001.

31. Kuzmichev A, Zhang Y, Erdjument-Bromage H, Tempst P and Reinberg D: Role of the Sin3-histone deacetylase complex in growth regulation by the candidate tumor suppressor $\mathrm{p} 33^{\mathrm{ING} 1}$. Mol Cell Biol 22: 835-848, 2002.

32. Feng X, Hara Y and Riabowol K: Different HATS of the ING1 gene family. Trends Cell Biol 12: 532-538, 2002.

33. Cheung KJ Jr, Bush JA, Jia W and Li G: Expression of the novel tumour suppressor $\mathrm{p} 33^{\mathrm{ING} 1}$ is independent of $\mathrm{p} 53$. Br J Cancer 83: 1468-1472, 2000. 